\title{
Combinatorial signaling by Sonic hedgehog and Wnt family members induces myogenic bHLH gene expression in the somite
}

\author{
Andrea E. Münsterberg, ${ }^{1}$ Jan Kitajewski, ${ }^{2}$ David A. Bumcrot, ${ }^{3}$ Andrew P. McMahon, ${ }^{3}$ \\ and Andrew B. Lassar ${ }^{1,4}$ \\ ${ }^{1}$ Department of Biological Chemistry and Molecular Pharmacology, Harvard Medical School, Boston, Massachusetts 02115 \\ USA; ${ }^{2}$ Department of Pathology and Center for Reproductive Sciences, Columbia University Medical School, New York, \\ New York 10032 USA; ${ }^{3}$ Department of Molecular and Cellular Biology, Harvard University, Cambridge, Massachusetts \\ 02138 USA
}

We have demonstrated previously that a combination of signals from the neural tube and the floor plate/notochord complex synergistically induce the expression of myogenic bHLH genes and myogenic differentiation markers in unspecified somites. In this study we demonstrate that Sonic hedgehog (Shh), which is expressed in the floor plate/notochord, and a subset of Wnt family members (Wnt-1, Wnt-3, and Wnt-4), which are expressed in dorsal regions of the neural tube, mimic the muscle inducing activity of these tissues. In combination, Shh and either Wnt-1 or Wnt-3 are sufficient to induce myogenesis in somitic tissue in vitro. Therefore, we propose that myotome formation in vivo may be directed by the combinatorial activity of Shh secreted by ventral midline tissues (floor plate and notochord) and Wnt ligands secreted by the dorsal neural tube.

[Key Words: Neural tube; floor plate; notochord; Shh; Wnts; myogenic bHLH; somitogenesis]

Received September 18, 1995; revised version accepted October 6, 1995.

In vertebrates, paraxial mesoderm, which lies adjacent to the neural tube and notochord, gives rise to transient cellular aggregates, termed somites. Initially, the somite is a sphere of epithelial cells. Subsequently, cells in the ventral half of the somite develop a mesenchymal morphology, termed the sclerotome, which contains precursor cells for vertebrae and ribs. The epithelial sheet that persists in the dorsal-most somite is termed the dermomyotome. The dermomyotome contains precursor cells for both skeletal muscle and dermis; cells located in the medial dermomyotome, adjacent to the neural tube, give rise to back and intercostal muscles (i.e., epaxial musculature; Ordahl and Douarin 1992); cells located in the lateral dermomyotome give rise to ventral body wall and limb muscles (i.e., hypaxial musculature; Ordahl and Douarin 1992); and an additional population of cells gives rise to some of the dermis within the back. Dermomyotomal cells that lie adjacent to the neural tube give rise to the myotome, a secondary sheet of differentiated skeletal muscle cells that lies between the dermomyotome and sclerotome.

The different somitic cell fates are cued by signals from surrounding tissues (Aoyama and Asamoto 1988;

${ }^{4}$ Corresponding author.
Christ et al. 1992; Ordahl and Douarin 1992; for review, see Christ and Ordahl 1995). Currently, there is a wealth of evidence indicating that signals from the neural tube and notochord are necessary to promote the proper formation of both sclerotome (Holtzer and Detwiler 1953; Watterson et al. 1954; Brand-Saberi et al. 1993; Dietrich et al. 1993; Goulding et al. 1993; Koseki et al. 1993; Pourquie et al. 1993) and myotome (Avery et al. 1956; Vivarelli and Cossu 1986; Kenny-Mobbs and Thorogood 1987; Christ et al. 1992; Rong et al. 1992; Bober et al. 1994; Buffinger and Stockdale 1994; Goulding et al. 1994; Buffinger and Stockdale 1995; Münsterberg and Lassar 1995; Stern and Hauschka 1995). Explant analysis has indicated that signals from either the notochord or floor plate of the neural tube are sufficient to induce chondrification of somitic cells /Grobstein and Holtzer 1955; Lash et al. 1957). In consonance with these earlier findings, it was demonstrated recently that Sonic hedgehog (Shh), a signaling molecule expressed in both floor plate and notochord (Echelard et al. 1993; Krauss et al. 1993; Riddle et al. 1993; Chang et al. 1994; Johnson et al. 1994; Roelink et al. 1994), can activate expression of a sclerotomal marker, Pax-1, in somitic cells (Fan and Tessier-Lavigne 1994; Johnson et al. 1994; Fan et al. 1995). 
We have found recently that myogenesis of somitic tissue in vitro [presegmental plate and somite stages I-III isolated from Hamburger-Hamilton (Hamburger and Hamilton 1951) stage 10 chick embryos] requires signals from both the notochord/floor plate complex and more dorsal regions of the neural tube (Münsterberg and Lassar 1995; see also Vivarelli and Cossu 1986; Kenny-Mobbs and Thorogood 1987; Rong et al. 1992; Buffinger and Stockdale 1994; Buffinger and Stockdale 1995; Stern and Hauschka 1995). In contrast, myogenesis in more mature somites (somite stages IV-VI) can occur in vitro in the presence of neural tube lacking floor plate/notochord (Münsterberg and Lassar 1995). [Following the numbering system of Ordahl, the most recently formed somite is termed stage I, and successively more rostral somites are termed somite stages II, III, etc. (Ordahl 1993; Christ and Ordahl 1995).] Neural tube adjacent to either presegmental plate mesoderm or somites IV-VI is capable of inducing myogenesis in somites IV-VI but does not induce myogenesis in presegmental plate from stage 10 embryos in the absence of floor plate/notochord (Münsterberg and Lassar 1995). This finding suggested that prior exposure to a ventral midline signal (i.e., emanating from the floor plate and/or notochord) had rendered somites IV-VI competent to respond to a muscle-inducing signal from the neural tube. In contrast, presegmental plate mesoderm from similar stage embryos had not yet received this ventral midline signal in vivo and therefore was incompetent to be induced to become skeletal muscle in vitro by signals from the neural tube. These findings have led us to propose that somite myogenesis is combinatorially induced by signals from both the floor plate and neural tube, and that the signal from the former is sent prior to the latter (Münsterberg and Lassar 1995).

In this study we demonstrate that somite myogenesis can be induced in presegmented paraxial mesoderm in vitro by administration of Shh in combination with some but not all Wnt ligands. Whereas presegmental plate mesoderm requires both Shh and Wnt signals to activate MyoD expression, more mature somites (stages IV-VI) require only Wnt signals. Wnt family members that induce somite myogenesis (Wnt-1, Wnt-3, and Wnt4) are expressed predominantly in the dorsal half of the developing neural tube and noninducing Wnt family members (Wnt-7a and Wnt-7b) are expressed predominantly in the ventral half of the neural tube. Therefore, we propose that myotome formation in vivo may be directed by the combinatorial activity of Shh secreted by ventral midline tissues (floor plate and notochord) plus Wnt ligands secreted by the dorsal neural tube.

\section{Results}

Shh acts in combination with signals from the neural tube to induce somite myogenesis

Presegmental plate mesoderm was isolated from a stage 10 chick embryo and cultured in vitro, in a collagen gel, either alone or in the presence of axial tissues. Following a 3-day culture period, RNA was isolated from the ex- plants and gene expression was assayed by reverse transcriptase-PCR (RT-PCR). Muscle-specific genes (myoD, myogenin, and myosin heavy chain) were highly expressed in presegmental plate mesoderm when cocultivated with neural tube plus the notochord/floor plate complex (Fig. 1A, lane 2). In contrast, muscle-specific genes were expressed either at only trace levels or were undetectable in presegmental plate mesoderm when cocultured with neural tube in the absence of ventral midline tissues (Fig. 1A, lanes 1,3). Notochord and floor plate are known to express Shh and ectopic expression of Shh in the dorsal somite expands the domain of $\mathrm{MyoD}$ expression (Johnson et al. 1994). Therefore, we tested whether bacterially produced Shh (peptide N3; Marti et al. 1995), which included the $19-\mathrm{kD}$ amino-terminal processed fragment of Shh plus 19 amino acids of the carboxy-terminal peptide (termed here as N-Shh), was sufficient to induce somite myogenesis in the presence of neural tube lacking floor plate. (In the following text we refer to neural tube lacking floor plate as "neural tube $-\mathrm{FP}^{\prime \prime}$.) The 19-kD amino-terminal-processed fragment of Shh has been shown previously to be sufficient to induce both Pax-1 expression in somitic tissue (Fan et al. 1995) and floor plate and/or motor neuron markers in intermediate neural tube cultures (Marti et al. 1995; Roelink et al. 1995). Addition of soluble N-Shh (175 ng/ ml) to presegmental plate mesoderm/neural tube -FP cocultures led to high-level expression of MyoD and myosin heavy chain plus the sclerotomal marker Pax-1 (Fig. 1A, lane 4). The trace levels of Shh transcript in this culture suggests that an ectopic floor plate was not induced in this explant (Fig. 1A, lane 4). Thus, the aminoterminal fragment of Shh can functionally substitute for the muscle-inducing capacity of floor plate/notochord. Addition of N-Shh to presegmental plate mesoderm cultured in the absence of the adjacent neural tube led to activation of Pax-1; however, no detectable somite myogenesis was observed (Fig. 1A, lane 6). These findings indicate that induction of myogenesis in presegmental plate mesoderm can be elicited by either the amino-terminal fragment of Shh or the floor plate/notochord complex (Münsterberg and Lassar 1995) in combination with signals from the neural tube -FP. N-Shh administration significantly increased glyceraldehyde-3-phosphate dehydrogenase (GAPDH) levels in presegmental plate mesoderm (Fig. 1A, cf. lanes 5 and 6), consistent with recent findings that Shh is mitogenic for this tissue (Fan et al. 1995). Whereas $\mathrm{N}-\mathrm{Shh}$ treatment of presegmental plate mesoderm is sufficient to activate Pax-1 expression and increase somitic cell number, $\mathrm{N}-\mathrm{Shh}$ administration alone is not sufficient to induce myogenesis in the absence of additional signals from the neural tube.

Because the amino-terminal fragment of Shh is capable of inducing both a sclerotomal marker (Pax-1) and myotomal markers in the presence of neural tube, we monitored whether these distinct somitic cell fates were induced by different concentrations of N-Shh (Fig. 1B). Titration of increasing amounts of $\mathrm{N}$-Shh plus presegmental plate mesoderm indicated that concentrations of $\mathrm{N}-\mathrm{Shh}(100 \mathrm{ng} / \mathrm{ml})$ that induced half maximal levels of 


\section{A}
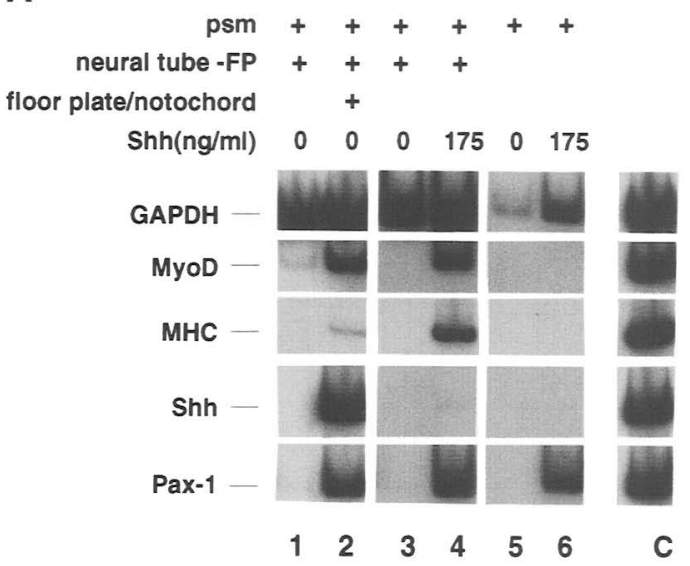

B
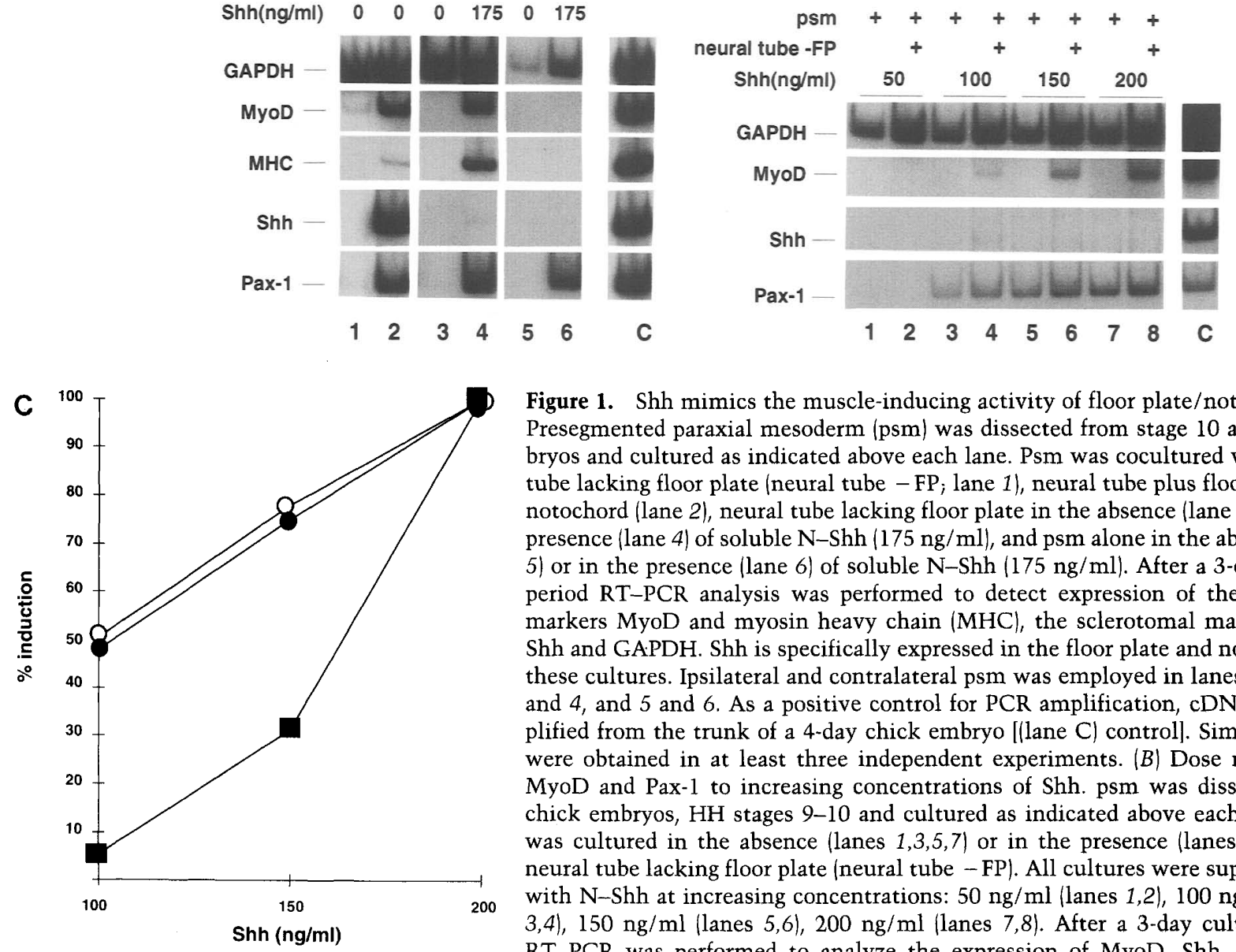

Figure 1. Shh mimics the muscle-inducing activity of floor plate/notochord. $(A)$ Presegmented paraxial mesoderm (psm) was dissected from stage 10 and 10- embryos and cultured as indicated above each lane. Psm was cocultured with neural tube lacking floor plate (neural tube - FP; lane 1), neural tube plus floor plate and notochord (lane 2), neural tube lacking floor plate in the absence (lane 3) or in the presence (lane 4) of soluble N-Shh $(175 \mathrm{ng} / \mathrm{ml})$, and psm alone in the absence (lane 5) or in the presence (lane 6) of soluble $\mathrm{N}-\mathrm{Shh}(175 \mathrm{ng} / \mathrm{ml})$. After a 3-day culture period RT-PCR analysis was performed to detect expression of the myogenic markers MyoD and myosin heavy chain (MHC), the sclerotomal marker Pax-1, Shh and GAPDH. Shh is specifically expressed in the floor plate and notochord in these cultures. Ipsilateral and contralateral psm was employed in lanes 1 and 2, 3 and 4 , and 5 and 6 . As a positive control for PCR amplification, cDNA was amplified from the trunk of a 4-day chick embryo [(lane C) control]. Similar results were obtained in at least three independent experiments. $(B)$ Dose response of MyoD and Pax-1 to increasing concentrations of Shh. psm was dissected from chick embryos, HH stages 9-10 and cultured as indicated above each lane. psm was cultured in the absence (lanes $1,3,5,7$ ) or in the presence (lanes 2,4,6,8) of neural tube lacking floor plate (neural tube - FP). All cultures were supplemented with N-Shh at increasing concentrations: $50 \mathrm{ng} / \mathrm{ml}$ (lanes 1,2), $100 \mathrm{ng} / \mathrm{ml}$ (lanes 3,4), $150 \mathrm{ng} / \mathrm{ml}$ (lanes 5,6), $200 \mathrm{ng} / \mathrm{ml}$ (lanes 7,8). After a 3-day culture period RT-PCR was performed to analyze the expression of MyoD, Shh, Pax-1, and GAPDH. Ipsilateral and contralateral psm was employed in lanes 1 and 2, 3 and 4, 5 and 6 , and 7 and 8 . Lane C displays cDNA amplified from 4-day embryo RNA as described in $A$. Similar results were obtained in two independent experiments. (C) Quantitation of dose response of MyoD and Pax-1 to increasing concentrations of Shh. Pax-1 and MyoD transcript levels were normalized to the relative levels of GAPDH transcript in each explant culture. Ratios of Pax-1/GAPDH and MyoD/GAPDH are plotted as percent induction of corresponding ratios obtained at $200 \mathrm{ng} / \mathrm{ml}$ of N-Shh. The $x$-axis displays increasing concentrations of soluble $\mathrm{N}-\mathrm{Shh}(100,150$, and $200 \mathrm{ng} / \mathrm{ml}$, respectively). The $y$-axis shows percent induction. (O) Pax-1 induction in psm cultured alone; (O) Pax-1 induction in psm cultured in the presence of neural tube $-\mathrm{FP} ;(\square)$ MyoD induction in psm cultured in the presence of neural tube - FP.

Pax-1 induced only trace levels of MyoD (in the presence of neural tube; Fig. 1B, lane 4). A dose-response curve comparing the relative levels of $\mathrm{MyoD}$ and Pax-1 induction in presegmental plate/neural tube - FP cocultures treated with increasing amounts of soluble N-Shh indicated that Pax-1 is more readily induced at lower concentrations of soluble N-Shh than is MyoD (Fig. 1C; cf. solid circles with filled squares). Whereas induction of MyoD by soluble N-Shh was absolutely dependent on the presence of adjacent neural tube - FP, Pax-1 was induced to comparable levels in the absence or presence of the neural tube (Fig. 1C; cf. solid and open circles). Thus, robust expression of myotomal markers in presegmental plate mesoderm requires (1) a higher concentration of the amino-terminal fragment of Shh than is necessary for induction of Pax-1, and (2) the presence of the adjacent neural tube.

Some Wnt family members mimic the muscle-inducing activity of the neural tube

Somitic myogenesis was not observed in presegmented plate mesoderm cocultured with neural tube - FP alone (Fig. 2A, lane 2). In contrast, myogenesis was induced in more rostrally located somites (somite stages IV-VI) after coculture with adjacent neural tube -FP (Fig. 2A, lane 4) but not after coculture with either the notochord/ floor plate complex (Münsterberg and Lassar 1995), the notochord alone (Fig. 2A, lane 8), or bacterially produced N-Shh (Fig. 2A, lane 12). However, both notochord and 

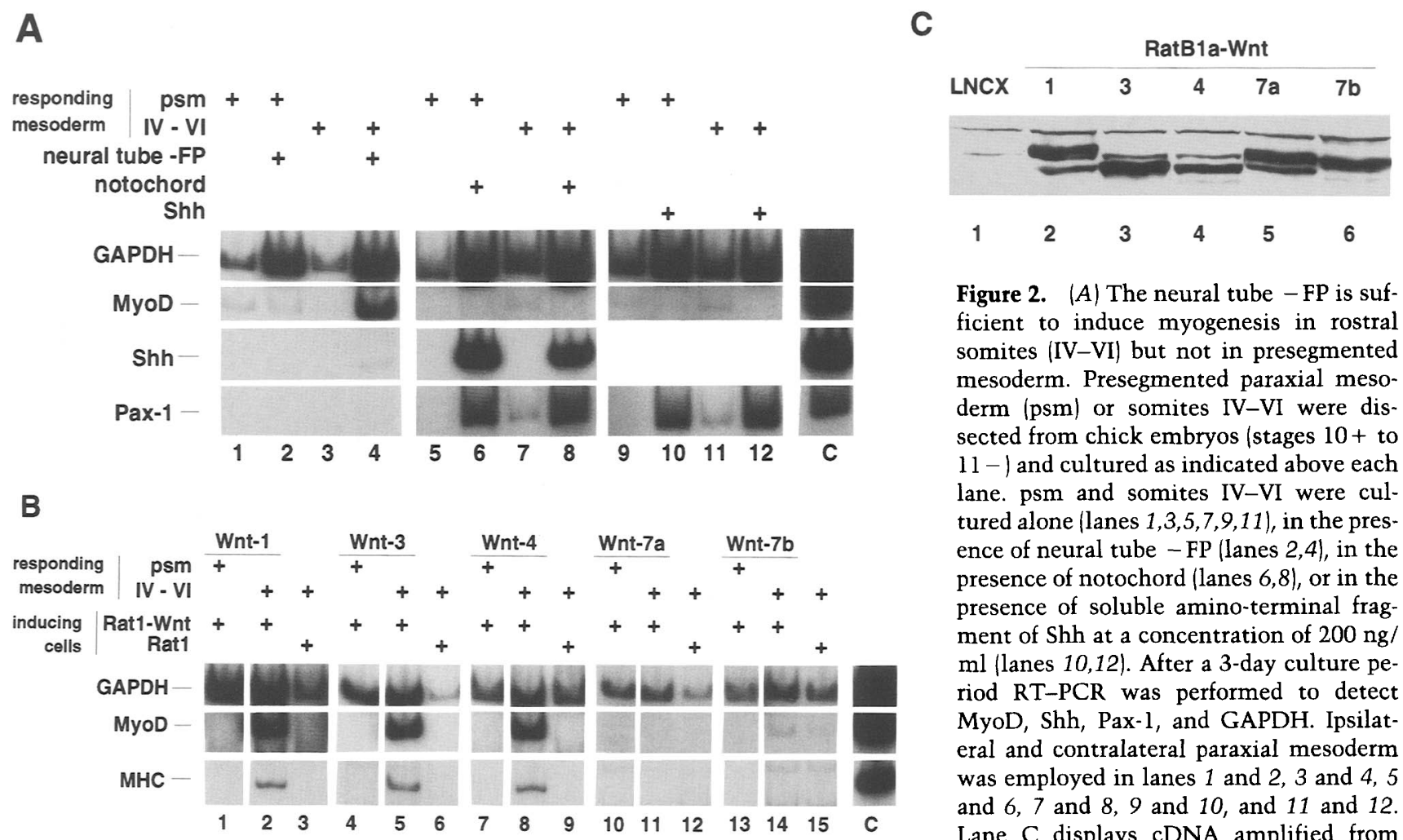

Figure 2. (A) The neural tube - FP is sufficient to induce myogenesis in rostral somites (IV-VI) but not in presegmented mesoderm. Presegmented paraxial mesoderm (psm) or somites IV-VI were dissected from chick embryos /stages $10+$ to $11-\mid$ and cultured as indicated above each lane. psm and somites IV-VI were cultured alone (lanes $1,3,5,7,9,11)$, in the presence of neural tube - FP (lanes 2,4), in the presence of notochord (lanes 6,8), or in the presence of soluble amino-terminal fragment of Shh at a concentration of $200 \mathrm{ng}$ / $\mathrm{ml}$ (lanes 10,12). After a 3-day culture period RT-PCR was performed to detect MyoD, Shh, Pax-l, and GAPDH. Ipsilateral and contralateral paraxial mesoderm was employed in lanes 1 and 2, 3 and 4, 5 and 6,7 and 8,9 and 10 , and 11 and 12 . Lane $C$ displays cDNA amplified from 4-day embryo RNA as described in Fig. 1A. Similar results were obtained in at least three independent experiments. $(B)$ Wnt -1 , Wnt -3 , and Wnt-4 are able to induce myogenesis in somites IV-VI, but not in psm. psm or somites IV-VI were dissected from chick embryos (stage $9+$ to $11-$ ) and cultured as indicated above each lane. psm and somites IV-VI were cultured with pellets of Rat Bla fibroblasts expressing retroviral encoded Wnt-1 (lanes 1,2), Wnt-3 (lanes 4,5), Wnt-4 (lanes 7,8), Wnt-7a (lanes 10,11), and Wnt-7b (lanes 13,14). The contralateral somites IV-VI (lanes $3,6,9,12,15$ ) and the contralateral psm (data not shown) were cultured with a pellet of Rat Bla fibroblasts infected with the parental retroviral expression vehicle LNCX, without an insert. After a 3-day culture period RT-PCR was performed to detect MyoD, MHC, and GAPDH. Lane C displays cDNA amplified from 4-day embryo RNA as described in Fig. 1A. Similar results were obtained in at least three independent experiments. $(C)$ Western analysis of Wnt protein levels in Rat Bla fibroblasts expressing ectopic Wnt cDNAs. Whole-cell lysates made from both parental Rat Bla fibroblasts infected with the LNCX expression vehicle or from Rat Bla fibroblasts expressing retroviral encoded, HA-tagged Wnt proteins were Western blotted to assay amounts of ectopic Wnt protein. The numbers above each lane indicate the ectopic Wnt protein expressed in each fibroblast line.

bacterially produced $\mathrm{N}-\mathrm{Shh}$ were capable of inducing Pax-1 gene expression in somites IV-VI (Fig. 2A, lanes 8,12 ) as well as in presegmental plate mesoderm (Fig. 2A, lanes 6,10$)$. We interpret these findings to indicate that factors present in neural tube - FP are sufficient to activate myogenesis in somites IV-VI; however, factors from the notochord or floor plate are not sufficient to induce myogenesis in these stage somites. A number of different Wnt family members are expressed along the entire A/P axis of the neural tube (Parr et al. 1993). In addition, Wnt family members have been demonstrated to modify mesodermal cell fate in Xenopus embryos (Smith and Harland 1991; Sokol et al. 1991; Christian and Moon 1993; Hume and Dodd 1993; Ku and Melton 1993). Therefore, we decided to test whether Wnt family members known to be expressed in the neural tube (i.e., Wnt-1, Wnt-3, Wnt-4, Wnt-7a, and Wnt-7b; Parr et al. 1993) mimic the muscle-inducing activity of this tissue.

Presegmental plate mesoderm or somites IV-VI (isolated from chick embryos, stages 9-10) were cocultured with either Rat B1a fibroblasts (Finney and Bishop 1993) programmed to express retrovirally encoded Wnt cDNAs or the parental Rat B1a fibroblast cell line infected with the retroviral expression vector LNCX (Miller and Rosman 1989). Coculture of Rat Bla cells programmed to express either Wnt-1, Wnt-3, or Wnt-4 with somites IVVI induced the expression of MyoD and myosin heavy chain (Fig. 2B, lanes 2,5,8); myogenesis in these somites was not observed after coculture with the parental Rat $\mathrm{Bla}$ cells (Fig. 2B, lanes 3,6,9). In contrast to the Wntmediated myogenesis observed in somites IV-VI, coculture of Rat Bla cells expressing Wnt-1, Wnt-3, or Wnt-4 did not activate myogenesis in presegmental plate mesoderm (Fig. 2B, lanes 1,4,7). The lack of myogenic differentiation in presegmental plate mesoderm cocultured with Rat Bla cells expressing Wnt-1, Wnt-3, or Wnt-4 was reminiscent of the absence of robust myogenesis in this tissue when cocultured with neural tube - FP (Fig. 2A, lane 2; Münsterberg and Lassar 1995). Cocultivation of somitic tissue with Rat B1a cells expressing either 
Wnt-1, Wnt-3, or Wnt-4 increased somitic GAPDH levels (Fig. 2B, cf. lanes 2 and 3, 5 and 6, 8 and 9), suggesting that these Wnt family members may affect both cell proliferation (see, e.g., Takada et al. 1994) as well as myogenesis in the somite.

In contrast to the robust myogenesis detected in somites IV-VI when cocultured with Rat Bla cells expressing either Wnt-1, Wnt-3 or Wnt-4, myogenesis was not observed in similar stage somites when cocultured with Rat Bla cells expressing either Wnt-7a or Wnt-7b (Fig. 2B, lanes 11,14). All of the Rat Bla-Wnt-expressing lines produced approximately the same amount of epitope-tagged Wnt protein as detected by Western blot analysis of total cell protein lysates (Fig. 2C). Thus, the absence of muscle gene expression after coculture of somites with cells expressing either Wnt-7a or Wnt-7b cannot be attributed to quantitative differences in the amount of Wnt expression in these cells. In summary, these findings indicate that some Wnt family members (Wnt-1, Wnt-3, and Wnt-4) are capable of inducing myogenesis in somites IV-VI, yet like signals from the neural tube - FP, are incapable of inducing myogenesis in presegmental plate mesoderm. In contrast, other Wnt family members (i.e., Wnt-7a and Wnt-7b) apparently cannot induce myogenesis in either presegmental plate mesoderm or somites IV-VI.

\section{Combinatorial action of Wnt and Shh are sufficient to induce somitic myogenesis}

Both neural tube - FP and fibroblasts expressing Wnt-1, Wnt-3 or Wnt-4 share the capacity to induce myogenesis in somites IV-VI but cannot induce myogenesis in presegmental plate mesoderm isolated before stage 11 . Because neural tube - FP is capable of inducing myogenesis in presegmental plate mesoderm when cultured in the presence of the soluble amino-terminal fragment of Shh (Fig. 1), we determined whether the combination of Wnt-expressing cells plus administration of soluble $\mathrm{N}-\mathrm{Shh}$ was sufficient to induce myogenesis in presegmental plate mesoderm. MyoD and myosin heavy chain expression were both induced in presegmental plate mesoderm when this tissue was cocultured with Rat B1a cells expressing either Wnt-1 or Wnt-3 in the presence of soluble N-Shh (Fig. 3, lanes 4,6). In contrast, culture of presegmental plate mesoderm with either $\mathrm{N}-\mathrm{Shh}$ in the presence of the parental Rat Bla fibroblasts (lane 2) or with the Wnt-producing Rat Bla fibroblasts alone (lanes $3,5)$ was not sufficient to induce myogenesis. These findings indicate that the combination of N-Shh plus either Wnt-1 or Wnt-3 is sufficient to induce myogenesis in presegmental plate mesoderm.

Shh signaling is continuously required for the maintenance of Pax-1 expression, but only transiently required for the induction of somite myogenesis

The above findings indicate that some Wnt family members together with Shh synergistically activate myogenesis in presegmental plate mesoderm. The ability of

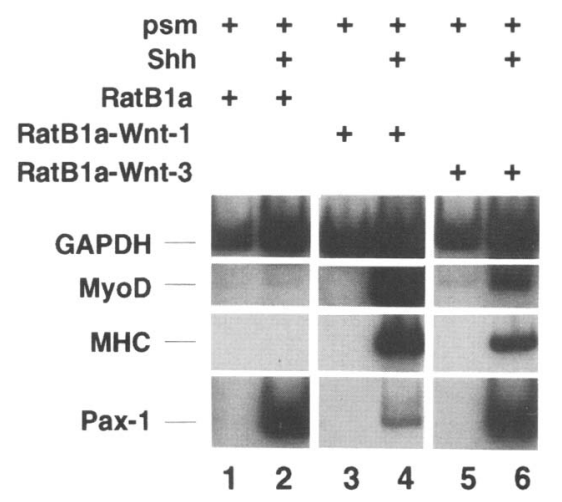

Figure 3. Shh and Wnt combinatorially induce myogenic bHLH gene expression in presegmented paraxial mesoderm (psm). psm was dissected from chick embryos (stages $9+$ and $10)$ and cultured as indicated above each lane. psm was cultured with pellets of Rat Bla fibroblasts infected with the retroviral expression vehicle LNCX, in the absence (lane 1) or the presence of N-Shh (200 ng/ml, lane 2), with pellets of Rat Bla fibroblasts expressing either retroviral encoded Wnt- 1 (lanes 3,4 ) or Wnt-3 (lanes 5,6) in the absence (lanes 3,5) or presence (lanes 4,6) of $\mathrm{N}-\mathrm{Shh}(200 \mathrm{ng} / \mathrm{ml})$. After a 3-day culture period RT-PCR was performed to detect MyoD, myosin heavy chain (MHC), Pax-1, and GAPDH. Similar results were obtained in at least three independent experiments.

more mature somites IV-VI to initiate myogenesis in response to Wnt signals in the absence of Shh (or neural tube in the absence of floor plate) suggests that somites IV-VI had been exposed previously to Shh signaling in the embryo. Interestingly, however, Pax-1 expression, which is induced by Shh (Fan and Tessier-Lavigne 1994; Johnson et al. 1994; Fan et al. 1995, and this study), is either undetectable or expressed at only trace levels in these somites (IV-VI) after coculture with either neural tube in the absence of floor plate (Fig. 2A, lane 4) or with Wnt-expressing cell lines (data not shown). Furthermore, whole-mount in situ hybridization studies have documented Pax-1 expression in somites IV-VI (Johnson et al. 1994; Ebensperger et al. 1995). Thus, the absence of detectable Pax-1 transcripts in somites IV-VI after in vitro culture suggests that continued exposure to Shh is necessary to maintain Pax-1 gene expression in somitic tissue. To test this possibility directly we examined Pax-1 expression in somites IV-VI either immediately following dissection of this tissue (Fig. 4A, lanes 1,3 ) or following in vitro culture of this tissue for $65 \mathrm{hr}$ in the absence or presence of soluble N-Shh (Fig. 4A, lanes 2 and 4, respectively|. We found that whereas somites IV-VI express readily detectable levels of Pax-1 immediately after dissection from a stage 10 embryo, this expression decays following $65 \mathrm{hr}$ in culture in the absence of N-Shh (Fig. 4A, lane 2). In contrast, in vitro culture of this tissue in the presence of soluble N-Shh is sufficient to sustain high level expression of Pax-1 (Fig. 4A, lane 4). These findings, together with those of others (Fan and Tessier-Lavigne 1994; Johnson et al. 1994; Fan et al. 19951, suggest that continued exposure to Shh is necessary to both initiate and maintain expression of Pax-1 in somitic mesoderm. 
A

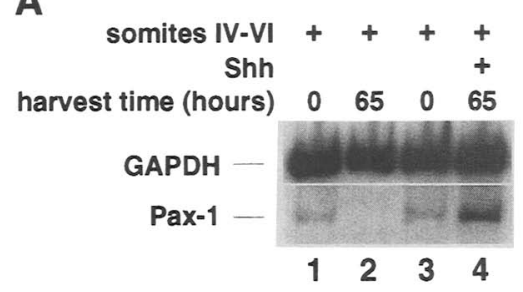

B

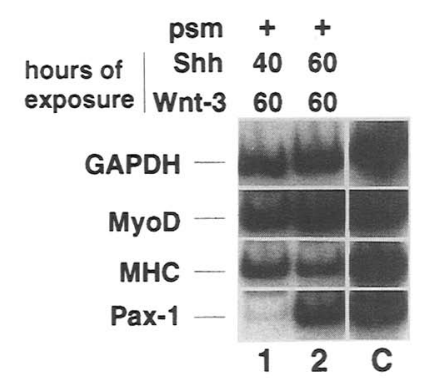

Figure 4. Shh signaling is continuously required for the maintenance of Pax-1 expression, however, only transiently required for induction of somite myogenesis. $(A)$ Somites IV-VI were dissected from a stage 10 chick embryo and analyzed for the expression of GAPDH and Pax-1 either immediately following dissection (lanes 1,3), or after in vitro culture for $65 \mathrm{hr}$ in the absence (lane 2) or the presence (lane 4) of N-Shh $(200 \mathrm{ng} / \mathrm{ml}$ ). (B) Presegmented paraxial mesoderm (psm) was dissected from chick embryos (stages $10+$ and $11-$ ) and cultured as indicated above each lane. psm was cultured with pellets of Rat Bla fibroblasts expressing Wnt-3 in the presence of N-Shh (200 ng) $\mathrm{ml}$ ) for an initial period of $40 \mathrm{hr}$. After $40 \mathrm{hr}$ the culture was washed twice with medium to remove all of the soluble N-Shh and then cultured in the absence of N-Shh for another $20 \mathrm{hr}$ (lane 1). psm was cultured in the presence of Rat $\mathrm{Bl}$ a fibroblasts expressing Wnt-3 and soluble N-Shh for a period of $60 \mathrm{hr}$ (lane 2). After a total culture period of $60 \mathrm{hr}$ RT-PCR was performed to detect MyoD, myosin heavy chain (MHC), Pax-1, and GAPDH. Lane C displays cDNA amplified from 4-day embryo RNA as described in Fig. 1A. Similar results were obtained in two independent experiments.

We were interested to discern whether continued exposure to Shh was also necessary to maintain somitic myogenesis. Presegmental plate mesoderm cultured for a 60-hr period with both Wnt-3-producing fibroblasts and soluble N-Shh expressed high levels of both Pax-1 and MyoD (Fig. 4B, lane 2). In contrast, presegmental plate mesoderm cultured with Wnt-producing cells and soluble N-Shh for an initial period of $40 \mathrm{hr}$ and only Wntproducing cells for the subsequent $20 \mathrm{hr}$ expressed robust levels of MyoD and myosin heavy chain, but only trace levels of Pax-1 (Fig. 4B, lane 1). The extremely low levels of Pax-1 gene expression following N-Shh withdrawal indicated that high-level expression of $\mathrm{MyoD}$ in this explant could not be attributed to residual amounts of Shh contaminating the culture medium following $\mathrm{N}-\mathrm{Shh}$ removal. These findings indicate that a temporary exposure ( $40 \mathrm{hr}$ treatment) of presegmental plate mesoderm to N-Shh is sufficient to induce stable high-level expression of MyoD (for at least $20 \mathrm{hr}$ ) when this tissue is cultured in the presence of a Wnt-3 signal.

\section{Discussion}

Previous studies have demonstrated that cell fate determination in the somite is cued by signals from adjacent tissues. Sclerotome can be induced by signals emanating from either the floor plate or notochord (Holtzer and Detwiler 1953; Watterson et al. 1954; Brand-Saberi et al. 1993; Pourquie et al. 1993), and loss of these ventral midline tissues leads to absence of sclerotome formation in vivo (Dietrich et al. 1993; Koseki et al. 1993). In contrast, myogenic differentiation in somitic precursor tissue (presegmental plate taken from stage 10 or younger embryos) in vitro is dependent on signals from both the floor plate/notochord complex in addition to signals present in more dorsal regions of the neural tube (Münsterberg and Lassar 1995). These findings are consistent with the observation that excision of either the neural tube (Christ et al. 1992; Rong et al. 1992; Bober et al. 1994) or notochord (Goulding et al. 1994) at early stages of development leads to the absence of myotomal muscle in the somite and indicate that signals from both the neural tube and ventral midline tissues are required for the differentiation of the myotome proper. Here we demonstrate that the muscle-promoting signal from the notochord/floor plate complex can be mimicked by a bacterially produced amino-terminal fragment of the signaling molecule Shh and that the muscle-promoting signal from the neural tube can be mimicked by cell lines programmed to express Wnt-1, Wnt-3 or Wnt-4. Because these signaling molecules are sufficient to induce somitic myogenesis in vitro and are expressed in the inducing tissues (Shh in the floor plate/notochord and Wnt-1, Wnt-3, and Wnt-4 in the dorsal neural tube), we propose that combinatorial signaling by these two classes of signaling molecules is required for axial myogenesis in vivo.

We cannot distinguish at present whether the robust muscle differentiation observed in somites cultured in the presence of Shh and Wnt ligands is attributable to the induction of myogenic precursors or to a clonal expansion of an already existing population of myogenic precursor cells. In situ hybridization studies have demonstrated that low-level expression of MyoD is first detectable in somite III (Ott et al. 1991; Pownall and Emerson 1992; A.E. Münsterberg and A.B. Lassar, unpubl.). However, more sensitive RT-PCR analyses have revealed that Myf-5 and MyoD transcripts are detectable in mouse and chick presegmented mesoderm (Kopan et al. 1994; A.E. Münsterberg and A.B. Lassar, unpubl.). Myogenic basic helix-loop-helix (bHLH) gene expression is no longer detectable after in vitro culture of presegmented mesoderm in the absence of inducing tissues or factors (data not shown). Somitic MyoD and myogenin expression in vivo is similarly initiated but not maintained in chick embryos lacking the neural tube (Bober et al. 1994). Together, these observations suggest that low- 
level myogenic bHLH gene expression is unstable in the absence of axial signals.

Although somitic cells require additional cues to assume a myogenic cell fate when explanted as a tissue block (Avery et al. 1956; Vivarelli and Cossu 1986; Kenny-Mobbs and Thorogood 1987; Rong et al. 1992; Buffinger and Stockdale 1994; Buffinger and Stockdale 1995; Münsterberg and Lassar 1995; Stern and Hauschka 1995; Stern et al. 1995), apparently such is not the case when somitic cells are plated as single cells /GeorgeWeinstein et al. 1994). Both somitic and presegmental plate cells have been found to differentiate into either chondrocytes or myocytes following trypsinization and in vitro culture (George-Weinstein et al. 1994). Together, these findings suggests that cell-cell interactions within the paraxial mesoderm act to restrain both myogenesis and chondrogenesis in this tissue in the absence of positive influences. Therefore, signals from the axial tissues that induce the formation of these somitic cell types may act by overcoming an intrinsic inhibitory signal in the intact somite.

\section{Shh serves multiple roles in somite patterning}

Shh is autocatalytically processed to yield a secreted amino-terminal $19-\mathrm{kD}$ fragment that is tightly associated with the producing cell and a carboxy-terminal 27 to $28-\mathrm{kD}$ fragment that is released into the medium (Lee et al. 1994; Bumcrot et al. 1995). With regard to somitic cells, the amino-terminal $19-\mathrm{kD}$ fragment of Shh has been demonstrated to be a mitogen (Fan et al. 1995), to induce the expression of a sclerotomal marker $(\mathrm{Pax}-1)$ in presegmental plate mesoderm (Fan et al. 1995; this report), to inhibit the expression of the dermomyotomal marker Pax-3 (Fan et al. 1995) and, finally, to promote myogenic differentiation in the presence of neural tube -FP or Wnt family members (this report). Although the amino-terminal $19-\mathrm{kD}$ fragment of Shh is predominantly cell associated, both notochord or COS cells programmed to express N-Shh can apparently activate the expression of Pax-1 at a distance of up to $200 \mu \mathrm{m}$ (Fan et al. 1995). However, because conjugation of Pax-1-expressing chick somites VI-X with mouse presegmented mesoderm did not induce expression of mouse Pax-1, it has been argued that Shh directly activates Pax-1 expression as opposed to inducing a cascade of signaling molecules that activate this sclerotomal marker (Fan and Tessier-Lavigne 1994). The amino-terminal fragment of Shh also plays a positive role in the differentiation of myogenic cells. In contrast, the carboxy-terminal fragment of Shh, which is readily secreted into the medium (Lee et al. 1994; Bumcrot et al. 1995), can neither mediate the induction of Pax-1 (Fan et al. 1995) nor activate myogenesis in presegmental plate mesoderm cocultured with Wnt-3-expressing fibroblasts (data not shown). Whereas the amino-terminal fragment of Shh is sufficient to induce somitic expression of Pax-1 (Fan et al. 1995; this report), Shh-mediated myogenesis requires an additional signal from either neural tube - FP or Wnt expressing fibroblasts.
It is not clear whether myogenic differentiation mediated by Shh is a direct effect of Shh on prospective myotomal cells (Fig. 5, left) or whether an intermediate signaling molecule(s) is induced (displayed $\mathrm{X}$ in Fig. 5, right) which then promotes myogenesis. We have found that levels of soluble $\mathrm{N}-\mathrm{Sh}$ sufficient to induce half maximal levels of Pax-1 induce only trace levels of $\mathrm{MyoD}$ (Fig. 1B) in vitro. This finding argues that Shh is not simply acting in a concentration-dependent manner to alter somitic cell fate in vivo, because this would be more consistent with sclerotome induction at high concentrations of N-Shh close to the notochord/floor plate and myotome induction at lower concentrations of $\mathrm{N}-\mathrm{Shh}$ further away from the notochord/floor plate. Rather, the paradoxical requirement for higher levels of Shh for induction of distal myotome versus proximal sclerotome are instead consistent with a dependency of myotome formation on (1) Shh-mediated induction of an intermediate signaling molecule, (2) the combinatorial activity of multiple axial signals, or (3) both of the above. In contrast to this complex scenario in the somite the situation seems to be different in the ventral neural tube where the induction of floor plate and/or motor neurons is thought to be directly determined by the local concentration of $\mathrm{N}-\mathrm{Shh}$; high levels inducing floor plate and lower levels inducing motor neurons (Marti et al. 1995; Roelink et al. 1995).

Whereas maintenance of somitic Pax-1 expression requires the continued presence of Shh, somite myogenesis in response to Wnt-expressing Rat Bla cells requires only temporary exposure to Shh. These findings indicate that Shh can induce both unstable and stable genetic programs in somitic cells and further highlight differences in Shh-mediated induction of sclerotome versus myotome. The stability of the myogenic program following Shh withdrawal in vitro suggests that Shh activates a

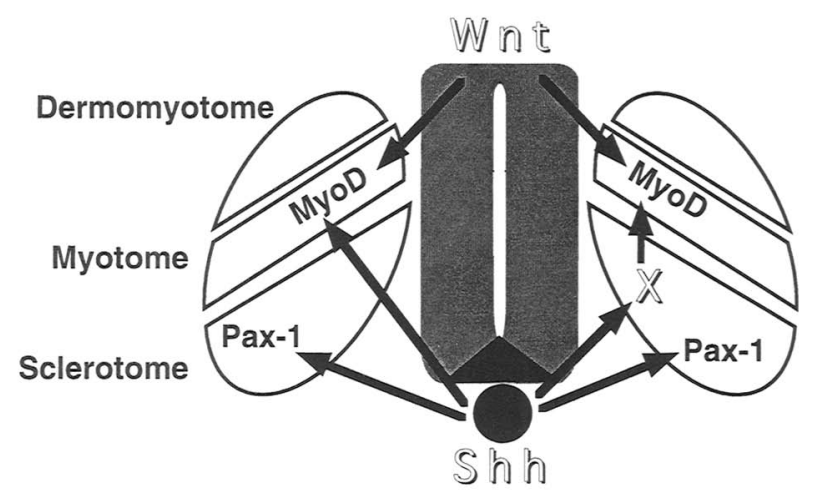

Figure 5. Shh and Wnt signals combinatorially pattern the somite. Shh secreted by both the floor plate and the notochord induces Pax-l expression in the ventral somite and mediates myotome formation more dorsally. Myotome differentiation requires both Shh and a Wnt signal from the neural tube. It is unclear whether Shh is acting directly on myogenic cells in combination with a Wnt signal (left) or whether Shh indirectly affects myogenic differentiation via an intermediate signaling molecule, depicted as " $\mathrm{X}$ " (right). 
positive regulatory loop that maintains $\mathrm{MyoD}$ expression. At present, it is unclear whether this positive loop entails the activation of an intermediate signaling molecule (Signal X in Fig. 5, right) or activation of the myogenic bHLH factors themselves. The ability of myogenic bHLH family members to activate their own synthesis (for review, see Weintraub 1993; Olson and Klein 1994) could explain the stability of myotomal gene expression following Shh withdrawal.

\section{Ventral midline tissues play both a positive and} negative role in the induction of myotome

The ability of the amino-terminal fragment of Shh to influence cell fates in both the ventral regions of the neural tube and in the somite is consistent with the requirement for notochord signals in the induction of floor plate (van Straaten et al. 1988; Smith and Schoenwolf 1989; Placzek et al. 1990; Yamada et al. 1991; Placzek et al. 1993), motor neurons (Yamada et al. 1993), sclerotome (Holtzer and Detwiler 1953; Watterson et al. 1954; Brand-Saberi et al. 1993; Dietrich et al. 1993; Koseki et al. 1993; Pourquie et al. 1993) and myotome (Goulding et al. 1994) and suggests that Shh plays a crucial role in polarization of both the axial and paraxial tissues. Surprisingly, however, implantation of ventral midline tissues between the neural tube and somite (Pourquie et al. 1993), or lateral to the somite (Brand-Saberi et al. 1993), has been demonstrated to induce sclerotome formation at the expense of myotome. However, in contrast to these results, direct infection of somites with a retrovirus encoding Shh led to an expansion of the myotome (Johnson et al. 1994). We think inhibition of myotome formation by implantation of ventral midline tissues adjacent to the somite could be attributable to (1) an alteration of the signaling properties of the neural tube, (2) the suppression of myogenesis by extremely high local concentrations of Shh, or (3) to the presence of a factor in notochord/floor plate (other than Shh) that represses myotome formation at close range.

\section{Combinatorial activation of myogenesis}

Three Wnt genes that are predominantly expressed in the dorsal regions of the neural tube (Wnt-1, Wnt-3, and Wnt-4) were each demonstrated to activate myogenesis in somites IV-VI but not in presegmental plate mesoderm. Presegmental plate mesoderm can form muscle in response to signals from both neural tube - FP or cells expressing either Wnt-1 or Wnt-3 by simultaneously exposing this tissue to $\mathrm{N}-\mathrm{Shh}$. It is formally possible that induction of somite myogenesis by Wnt-producing cell lines was attributable to a Wnt-mediated induction of a secondary signaling molecule in the Wnt-producing cell lines themselves. Although we cannot rule out this possibility, we feel that this is unlikely given the ability of three different Wnt ligands to elicit this effect while two of the Wnt-ligands were unable to promote myogenesis. In addition, Rat Bla fibroblast have shown no phenotypic changes attributable to Wnt gene expression. Various Wnt family members differ in their capacity to transform mammary epithelial cells (Wong et al. 1994), induce axis duplication in Xenopus embryos (for review, see Du et al. 1995), or induce somitic myogenesis (this report). It is unclear what properties of these signaling molecules account for their differential activities in these assays. Wnt family members that induce somitic myogenesis include those that can transform mammary epithelial cells (Wnt-1 and Wnt-3) and at least one member that is nontransforming in this assay system (i.e., Wnt-4; Wong et al. 1994).

Currently, the localization of the muscle-inducing activity in the neural tube is somewhat controversial. Whereas Stockdale and colleagues have reported that dorsal neural tube contains an inhibitor of myogenesis and that muscle inducing activity is preferentially located in the ventral neural tube (Buffinger and Stockdale 1995), Hauschka and colleagues have found that muscleinducing activity is preferentially localized to the dorsal neural tube and have found that coculture of somites with Wnt-1-expressing cells can induce somitic myogenesis (Stern et al. 1995). In concert with these latter findings, we have found that Wnt-1, Wnt-3, and Wnt-4, which are expressed predominantly in the dorsal half of the neural tube (Parr et al. 1993), all induce somitic myogenesis. In contrast, Wnt-7a and Wnt-7b, which do not induce somitic myogenesis in vitro, are expressed mainly in the ventral half of the neural tube (Parr et al. 1993). Thus, myotome formation, which is known to be dependent on both neural tube (Christ et al. 1992; Rong et al. 1992; Bober et al. 1994) and notochord (Goulding et al. 1994) may be cued specifically by the combined action of Wnt family members in the dorsal half of the neural tube and Shh expressed by the ventral midline tissues (as illustrated in Fig. 5). Ultimately, functional tests in vivo will be necessary to clarify the role that specific Wnt family members play in the induction of myotomal muscle.

It has been demonstrated recently that signals from the dorsal half of the neural tube can inhibit muscle differentiation in specified somites (i.e., somites VII-XII from stage 12-14 embryos, which are capable of myogenic differentiation in the absence of further signaling from axial tissues; Buffinger and Stockdale 1995). This finding, together with the results of the present study, suggests that dorsal regions of the neural tube contain both positive and negative influences for myogenesis that together may act to define the final position of the myotome in the dorsomedial part of the somite. In addition to the axial tissues (neural tube and notochord) the ectoderm overlying the somite can also induce somite myogenesis in vitro (Kenny-Mobbs and Thorogood 1987; R. Reshef and A.B. Lassar, unpubl.). Wnt family members are expressed in the ectoderm overlying the somite (i.e., Wnt-4 and Wnt-6; Parr et al. 1993) and therefore may mediate the ability of this tissue to induce myogenic differentiation. It has been demonstrated recently that surface ectoderm is either necessary to maintain or initiate the expression of several dermomyotomal markers (Fan and Tessier-Lavigne 1994; Kuratani et al. 1994), although it is unclear in this case which signaling molecules are responsible for these effects. 
The synergistic induction of somite myogenesis by Wnt family members and Shh resembles the synergistic induction of dorsal mesoderm in Xenopus by Wnt genes plus either fibroblast growth factor (FGF) (Christian et al. 1992) or transformation growth factor- $\beta$ (TFG- $\beta$ ) family members (Sokol et al. 1991). In Xenopus, myogenic bHLH gene expression is activated prior to somitogenesis, whereas in amniotes this regulatory family is activated after somites have formed. It is our speculation that similar signaling molecules activate the myogenic program in these different organisms and that the temporal and spatial differences that mark the onset of myogenesis in avians and amphibia reflect underlying differences in the patterns of expression of the relevant signaling molecules. The above findings in vertebrate systems, together with recent findings that induction of a subset of the somatic musculature in Drosophila requires the wingless gene product (A. Martinez-Arias and M. Bate, pers. comm.|, raise the possibility that induction of skeletal muscle shares a common signaling pathway in metazoa.

\section{Materials and methods}

\section{Chick embryo dissections and culture of tissues}

Fertilized chick eggs (Spafas) were incubated at $38.5^{\circ} \mathrm{C}$ in a humidified incubator (Petersime). Embryos were staged according to Hamburger and Hamilton (1951), collected in silicon (Dow Corning)-coated petri dishes containing Tyrode's buffer (10X stock: 80 grams/liter of $\mathrm{NaCl}, 2$ grams/liter of $\mathrm{KCl}, 2$ grams/ liter of $\mathrm{CaCl}_{2}, 0.5$ gram/liter of $\mathrm{NaH}_{2} \mathrm{PO}_{4} 2$ grams/liter of $\mathrm{MgCl}_{2}$, and 10 grams/liter of glucose, and pinned down with their ventral side facing up using insect pins. To facilitate dissection, three drops of Tyrode's buffer containing dispase (Boehringer Mannheim, $1 \mathrm{mg} / \mathrm{ml}$ ) were added to each embryo using a glass pasteur pipette. The endodermal epithelium was removed from the region to be dissected, and the following tissues were explanted using micro feather scalpels (Oasis, CA): paraxial mesoderm (1) alone, (2) with the adjacent neural tube, floor plate and notochord, (3) with the adjacent neural tube excluding floor plate, (4) with floor plate and notochord, (5) or with notochord (see figure legends for details and stages of embryos). After washing in $\alpha$-minimal essential medium ( $\alpha$-MEM) (GIBCO) supplemented with $10 \%$ heat-inactivated horse serum (GIBCO), 2\% chick embryo extract and 1\% penicillin/streptomycin solution, the tissues were cultured in collagen gels in four-well dishes (Nunc). The cultures were maintained in $\alpha$-MEM (GIBCO) supplemented with $10 \%$ heat-inactivated horse serum (GIBCO), $2 \%$ chick embryo extract, $1 \mathrm{ng} / \mathrm{ml}$ of FGF (to improve the survival of presegmented paraxial mesoderm; data not shown) and 1\% Penn./Strep. solution, for 3 days in $5 \%$ $\mathrm{CO}_{2}$ at $37^{\circ} \mathrm{C}$. When indicated, the medium was supplemented with bacterially produced Shh (fragment N3, Marti et al. 1995). Chick embryo extract was prepared as described elsewhere (Münsterberg and Lassar 1995). Preparation of Rat Bla fibroblast pellets was essentially as described by (Riddle et al. 1993). The pellets were cut in small pieces approximately the same size as the paraxial mesoderm, transferred to the culture dish, juxtaposed to the chick tissues, and embedded in collagen.

\section{Preparation of rat tail collagen and embedding of tissues}

Collagen was prepared from $\sim 10$ adult rat tails. The tendons were isolated and dissolved for $24 \mathrm{hr}$ in $150 \mathrm{ml}$ of $3 \%$ glacial acetic acid at $4^{\circ} \mathrm{C}$. The undissolved debris was pelleted by centrifugation at $20,000 \mathrm{~g}$ for $60 \mathrm{~min}$. The supernatant was dialyzed over 3 days against 3 liters of sterile $0.1 \times \mathrm{DME}$ at $\mathrm{pH} 4.0$. The recovered collagen was stored in aliquots at $4^{\circ} \mathrm{C}$. For embedding of tissue explants we used a $65 \%$ solution of the collagen stock. The collagen was buffered by adding $1 / 10$ volume of a $10 \times$ DME at $\mathrm{pH} 4.0$ solution and $\sim 1 / 100$ volume of a $0.8 \mathrm{M} \mathrm{NaHCO}_{3}$ solution. To prevent gelling, the collagen solution was then kept on ice until use. A bed of collagen (6 $\mu 1$ volume) was prepared in the culture well, and the collagen gelled within $15 \mathrm{~min}$ at room temperature. The tissues and cell pellets were then placed on top of the collagen bed, excess medium was removed, and the explants were covered with $3 \mu$ l of collagen. The tissues and cell pellets were positioned before the top collagen gelled; after 15 min at room temperature, the culture was covered with medium.

\section{RNA isolation and reverse transcription}

At the end of the culture period medium was aspirated and RNA was prepared from the explants using the method described by Chomczynski and Sacchi (1987). Explants in collagen gels were lysed in $200 \mu \mathrm{l}$ of lysis buffer $(25$ grams of guanidinium thiocyanate, $1.76 \mathrm{ml}$ of $0.75 \mathrm{M}$ sodium citrate at $\mathrm{pH} 7,2.64 \mathrm{ml}$ of $10 \%$ Sarkosyl, $38 \mu \mathrm{l} \beta$-mercaptoethanol, and $29.3 \mathrm{ml}$ of $\mathrm{H}_{2} \mathrm{O}$ ) and transferred to a $1.5-\mathrm{ml}$ centrifuge tube; $20 \mu \mathrm{l}$ of $2 \mathrm{M}$ sodium acetate at $\mathrm{pH} 4$ and $200 \mu \mathrm{l}$ of water-saturated phenol were added and mixed, and $40 \mu \mathrm{l}$ of chloroform/isoamyl alcohol (49:1) was added, mixed, and incubated on ice for $15 \mathrm{~min}$. Following centrifugation at $4^{\circ} \mathrm{C}$ the supernatant was removed, glycogen was included as a carrier $(1.5 \mu \mathrm{l}$ of RNase free glycogen, $20 \mathrm{mg} / \mathrm{ml}$, Boehringer Mannheim |, and the RNA was precipitated with 500 $\mu l$ of ethanol in a new tube. After precipitation at $-80^{\circ} \mathrm{C}$ for at least $1 \mathrm{hr}$, the RNA was pelleted by centrifugation at $4^{\circ} \mathrm{C}$ for 20 min, washed with $80 \%$ ethanol, air-dried, and resuspended in 50 $\mu \mathrm{l}$ of buffer ( $40 \mathrm{~mm}$ Tris at $\mathrm{pH} 8.0,10 \mathrm{mM} \mathrm{NaCl} ; 6 \mathrm{~mm} \mathrm{MgCl}$ ) containing $0.5 \mu \mathrm{l}$ of DNase (RNase-free DNase, Boehringer Mannheim, $40 U / \mu l$ ) and $0.1 \mu \mathrm{l}$ RNase inhibitor (U.S. Biochemical $120 \mathrm{U} / \mu 1)$. This solution was incubated for $1 \mathrm{hr}$ at $37^{\circ} \mathrm{C}$, then extracted with Tris-buffered phenol/chloroform and precipitated at $-80^{\circ} \mathrm{C}$ by adding $10 \mu \mathrm{l}$ of $2 \mathrm{M} \mathrm{NaAcetate}$ at $\mathrm{pH} 4.5$, and $150 \mu \mathrm{l}$ of ethanol. After centrifugation the RNA pellet was washed twice with $80 \%$ ethanol, air-dried, dissolved in $10 \mu \mathrm{l}$ of DEPC-treated $\mathrm{H}_{2} \mathrm{O}$, and kept at $-80^{\circ} \mathrm{C}$.

Before cDNA synthesis the RNA was incubated at $65^{\circ} \mathrm{C}$ for 3 min then immediately cooled on ice, $5 \mu$ l were added to a $25-\mu \mathrm{l}$ reverse transcription cocktail, containing $1 \times$ transcription buffer (as provided by Bethesda Research Laboratories [BRL]), $0.5 \mathrm{~mm}$ of each $\mathrm{dNTP}, 200 \mathrm{ng}$ of a random hexamer primer, 0.1 $\mu$ l of RNase inhibitor, $3.3 \mathrm{~mm}$ DTT, and 200 units of MoMuLVreverse transcriptase (BRL) and incubated at $42^{\circ} \mathrm{C}$ for $1 \mathrm{hr}$. The cDNA was kept at $-20^{\circ} \mathrm{C}$ until used for PCR analysis.

\section{PCR amplification}

cDNA ( $1 \mu$ l) was used as template for each PCR amplification. Each $25-\mu \mathrm{l}$ reaction contained $50 \mathrm{mM} \mathrm{KCl}, 10 \mathrm{~mm}$ Tris/ $\mathrm{HCl}$ at $\mathrm{pH} 7,1.5 \mathrm{~mm} \mathrm{MgCl}_{2}, 0.01 \%$ gelatin, $200 \mathrm{~mm}$ of each dNTP, 0.1 $\mathrm{mCi} \mathrm{a}\left[{ }^{32} \mathrm{P}\right] \mathrm{dCTP} / 3000 \mathrm{Ci} / \mathrm{mm}$, $500 \mathrm{ng}$ of the appropriate primers, and 1 unit of Taq polymerase (Boehringer Mannheim). Shh and Pax-1 cDNAs were amplified in the presence of $5 \%$ formamide. After an initial denaturation step of $93^{\circ} \mathrm{C}$ for $3 \mathrm{~min}$, the reactions were cycled between $93^{\circ} \mathrm{C}(30 \mathrm{sec}), 60^{\circ} \mathrm{C}(30 \mathrm{sec}$, for $\mathrm{MyoD}, \mathrm{MHC}, \mathrm{GAPDH})$ or $49^{\circ} \mathrm{C}$ (30 sec, for Pax-1 and Shh) and 
$72^{\circ} \mathrm{C}(1 \mathrm{~min})$ in a $\left.\mathrm{M}\right)$ Research thermocycler. The reaction products for MyoD, myosin heavy chain, Pax-1, and Shh were amplified for 30 cycles while the product of GAPDH was amplified for 23 cycles. It was determined that after 23 cycles of amplification the GAPDH transcript was in the linear range. GAPDH is ubiquitously expressed and served as a control for the amount of cDNA present in each amplification reaction. We chose 30 cycles of amplification for the other cDNAs to detect trace amounts of gene products that were induced during in vitro culture. Depending on the amount of template in the culture, 30 cycles of amplification of the myogenic bHLH gene products were usually within the linear range. PCR reaction $(5 \mu l$ of each) was analyzed on a $6 \%$ polyacrylamide gel, which was dried and exposed to X-ray film at $-20^{\circ} \mathrm{C}$ for $16 \mathrm{hr}$. The following primers were used: MyoD (Lin et al. 1989, nucleotides 620-639) 5'CGTGAGCAGGAGGATGCATA-3', (nucleotides 864-883) 5'GGGACATGTGGAGTTGTCTG-3'; myosin heavy chain (Kavinsky et al. 1983, nucleotides 392-411) 5'-GATCCAGCTGAGCCATGCCA-3', (nucleotides 1008-989) 5'-GCTTCTGCTCAGCATCAACC-3'; Pax-1 [kindly provided by Rudi Balling (Institut für Sangetiergenetik, Oberschliessheim, Germany) and Haruhiko Koseki (Center for Biomedical Science, Chiba, Japan)] 5'-GCTGGGTGGTGTCTTCGTGA-3', (nucleotides 52-71), 5'GAATACAAGCAGGGCGACCC-3', (nucleotides 287-306); Shh (Riddle et al. 1993, nucleotides 186-205) 5'-TGGAAGATATGAAGGGAAGA-3', (nucleotides 561-580) 5'-CTGAGTTTTCTGCTTTGACG-3'; GAPDH (Dugaiczyk et al. 1983, nucleotides 680-699), 5'-AGTCATCCCTGAGCTGAATG-3', (nucleotides 990-1009) 5' -AGGATCAAGTCCACAACACG-3'. The expected product sizes are as follows: MyoD, $280 \mathrm{bp}$; MHC, 616 bp; Pax-1, 255 bp; Shh, 395 bp; GAPDH, 330 bp. In all cases, PCR amplification was shown to be dependent on reverse transcription of RNA templates and on the presence of both forward and reverse primers in the PCR reaction. The identity of each of the PCR products was confirmed by restriction enzyme digestion, and in each case the expected size fragments were obtained. The GAPDH primers amplified only the chick GAPDH cDNA from cocultures of Rat Bla fibroblasts and chick paraxial mesoderm (data not shown). PCR products were quantitated on a PhosphorImager (Molecular Dynamics).

\section{Immunoblotting}

A $80 \%$ confluent $6-\mathrm{cm}$ dish of rat Bla fibroblasts was lysed in $250 \mu$ l of $2 \times$ SDS sample buffer (Ausubel et al. 1993). The whole cell lysate was boiled for $2 \mathrm{~min}$ and sonicated in a BransonSonifier 450-Sonicator. Extract volumes containing equivalent amounts of DNA were determined by fluorimetry using a Hoefer TKO-100 minifluorometer and volumes of extract normalized for equivalent DNA content were resolved on a $10 \%$ SDSpolyacrylamide gel and electrophoretically transferred to nitrocellulose membrane (Schleicher \& Schuell) using a Bio-Rad trans-blot semidry transfer cell. The membranes were blocked over night at $4^{\circ} \mathrm{C}$ with $5 \%$ milk powder in PBT (PBS, $0.1 \%$ Tween 20, Fisher Biotech). The membranes were incubated for $3 \mathrm{hr}$ at room temperature with a 1:50 dilution of the primary anti-HA monoclonal 12CA5 in the blocking solution. The membranes were washed three times for $15 \mathrm{~min}$ in PBT and then incubated for $1.5 \mathrm{hr}$ at room temperature with the secondary antibody, HRP-donkey-anti-mouse (Jackson Immuno Research), at a dilution of 1:5000 in blocking solution. The membranes were washed as described previously and then detected using chemiluminescence according to the manufacturer's protocol (ECL, Amersham).

\section{Production of soluble Shh}

Bacterial production and purification of the $19-\mathrm{kD}$ amino-terminal fragment $\mathrm{N} 3$ and the $27-\mathrm{kD}$ carboxy-terminal fragments of Shh are described in Marti et al. (1995).

\section{Rat B1a fibroblast cell lines}

The Rat Bla fibroblast cell lines were generated as described in $Z$. Zheng and J. Kitajewski (in prep.). Cells were grown in Dulbecco's modified Eagle medium (DMEM) (GIBCO) containing $10 \%$ FBS, $1 \%$ Penn/Strep. solution, $1 \%$ glutamine, and $250 \mu \mathrm{g} /$ $\mathrm{ml}$ of G418. Fresh aliquots of cells were thawed every 2-3 weeks.

\section{Acknowledgments}

We thank Mark Tessier-Lavigne and Chen-Ming Fan for their collagen preparation protocol and for sharing unpublished information; Alfonso Martinez-Arias, Michael Bate, and Steve Hauschka for sharing unpublished information; Rudi Balling and Haruhiko Koseki for sharing quail Pax-l sequence information; Jim Rhee and Zhili Zheng for excellent technical assistance; Elisa Marti, Tom Schultheiss, Hazel Sive, Doug Spicer, and Grant Wheeler for informative discussions; and members of the Lassar laboratory for comments on the manuscript. A.E.M. and D.A.B. were supported by fellowships from the Muscular Dystrophy Association. This work was supported by grants to A.B.L. from the National Science Foundation (NSF) and a Basil O'Connor Award (1-FY94-0869) from the March of Dimes Birth Defects Foundation; by grants to A.P.M. from the National Institutes of Health (NS33642) and the Human Frontiers Science Program, and grants to J.K. from the American Cancer Society (DB-81) and the U.S. Army Medical Research and Material Command under grant DAMD17-94-J-4069. This work was done during the tenure of an established investigatorship from the American Heart Association to A.B.L.

The publication costs of this article were defrayed in part by payment of page charges. This article must therefore be hereby marked "advertisement" in accordance with 18 USC section 1734 solely to indicate this fact.

\section{References}

Aoyama, H. and K. Asamoto. 1988. Determination of somite cells: Independence of cell differentiation and morphogenesis. Development 104: 15-28.

Ausubel, F., R. Brent, R. Kingston, D. Moore, J. Seidman, J. Smith, and K. Struhl. 1993. Current protocols in molecular biology. Vol. 2, Chapter 10.2.17. John Wiley \& Sons, New York.

Avery, G., M. Chow, and H. Holtzer. 1956. An experimental analysis of the development of the spinal column. I. Exp. Zool. 132: 409-425.

Bober, E., B. Brand-Saberi, C. Ebensperger, J. Wilting, R. Balling, B.M. Paterson, H.-H. Arnold, and B. Christ. 1994. Initial steps of myogenesis in somites are independent of influence from axial structures. Development 120: 3073-3082.

Brand-Saberi, B., C. Ebensperger, J. Wilting, R. Balling, and B. Christ. 1993. The ventralizing effect of the notochord on somite differentiation in chick embryos. Anat. Embryol. 188: 239-245.

Buffinger, N. and F.E. Stockdale. 1994. Myogenic specification in somites: Induction by axial structures. Development 120: $1443-1452$. 
1995. Myogenic specification of somites is mediated by diffusible factors. Dev. Biol. 169: 96-108.

Bumcrot, D.A., R. Takada, and A.P. McMahon. 1995. Proteolytic processing yields two secreted forms of sonic hedgehog. Mol. Cell. Biol. 15: 2294-2303.

Chang, D.T., A. Lopez, D.P.v. Kessler, C. Chiang, B.K. Simandl, R. Zhao, M.F. Seldin, J.F. Fallon, and P.A. Beachy. 1994 Products, genetic linkage and limb patterning activity of a murine hedgehog gene. Development 120: 3339-3353.

Chomczynski, P. and N. Sacchi. 1987. Single-step method of RNA isolation by acid guanidinium thiocyanate-phenolchloroform extraction. Anal. Biochem. 162: 156-159.

Christ, B. and C.P. Ordahl. 1995. Early stages of chick somite development. Anat. Embryol. 191: 381-396.

Christ, B., B. Brand-Saberi, M. Grim, and J. Wilting. 1992. Local signalling in dermomyotomal cell type specification. Anat. Embryol. 186: 505-510.

Christian, J.L. and R.T. Moon. 1993. Interactions between $X W n t-8$ and Spemann organizer signaling pathways generate dorsoventral pattern in the embryonic mesoderm of Xenopus. Genes \& Dev. 7: 13-28.

Christian, J.L., D.J. Olson, and R.T. Moon. 1992. Xwnt 8 modifies the character of mesoderm induced by bFGF in isolated Xenopus ectoderm. EMBO I. 11 33-41.

Dietrich, S., F.R. Schubert, and P. Gruss. 1993. Altered Pax gene expression in murine notochord mutants: The notochord is required to initiate and maintain ventral identity in the somite. Mech. Dev. 44: 189-207.

Du, S.J., S.M. Purcell, J.L. Christian, L.L. McGrew, and R.T. Moon. 1995. Identification of distinct classes of functional domains of Wnts through expression of wild-type and chimeric proteins in Xenopus embryos. Mol. Cell. Biol. 15: 2625-2634.

Dugaiczyk, A., J.A. Haron, E.M. Stone, O.E. Dennison, K.N. Rothblum, and R.J. Schwartz. 1983. Cloning and sequencing of a deoxyribonucleic acid copy of glyceraldehyde-3-phosphate dehydrogenase messenger ribonucleic acid isolated from chicken muscle. Biochemistry 22: 1605-1613.

Ebensperger, C., J. Wilting, B. Brand-Saberi, Y. Mizutani, B. Christ, R. Balling, and H. Koseki. 1995. Pax-1, a regulator of sclerotome development is induced by notochord and floor plate signals in avian embryos. Anat. Embryol. 191: 279310.

Echelard, Y., D.J. Epstein, B. St-Jacques, L. Shen, J. Mohler, J.A. McMahon, and A.P. McMahon. 1993. Sonic hedgehog, a member of a family of putative signaling molecules, is implicated in the regulation of CNS polarity. Cell 75: 14171430.

Fan, C.-M. and M. Tessier-Lavigne. 1994. Patterning of mammalian somites by surface ectoderm and notochord: Evidence for sclerotome induction by a hedgehog homolog. Cell 79: 1175-1186

Fan, C.-M., J.A. Porter, C. Chiang, D.T. Chang, P.A. Beachy, and M. Tessier-Lavigne. 1995. Long-range sclerotome induction by sonic hedgehog: Direct role of the amino-terminal cleavage product and modulation by the cyclic AMP signaling pathway. Cell 81: 457-465.

Finney, R.E. and J.M. Bishop. 1993. Predisposition to neoplastic transformation caused by gene replacement of H-rasl. Science 260: 1524-1527.

George-Weinstein, M., J.V. Gerhart, G.J. Foti, and J.W. Lash. 1994. Maturation of myogenic and chondrogenic cells in the presomitic mesoderm of the chick embryo. Exp. Cell Res. 211: 263-274.

Goulding, M.D., A. Lumsden, and P. Gruss. 1993. Signals from the notochord and floor plate regulate the region-specific expression of two Pax genes in the developing spinal cord. Development 117: 1001-1016.

Goulding, M., A. Lumsden, and A.J. Paquette. 1994. Regulation of Pax-3 expression in the dermomyotome and its role in muscle development. Development 120: 957-971.

Grobstein, C. and H. Holtzer. 1955. In vitro studies of cartilage induction in mouse somite mesoderm. I. Exp. Zool. 128: 333-356.

Hamburger, V. and H.L. Hamilton. 1951. A series of normal stages in the development of the chick embryo. J. Morphol. 88: 49-92.

Holtzer, H. and S.R. Detwiler. 1953. An experimental analysis of the development of the spinal column. III. Induction of skeletogenous cells. J. Exp. Zool. 123: 335-370.

Hume, C.R. and J. Dodd. 1993. Cwnt-8c: A novel Wnt gene with a potential role in primitive streak formation and hindbrain organization. Development 119: 1147-1160.

Johnson, R.L., E. Laufer, R.D. Riddle, and C. Tabin. 1994. Ectopic expression of Sonic hedgehog alters dorsal-ventral patterning of somites. Cell 79: 1165-1173.

Kavinsky, C.J., P.K. Umeda, A.M. Sinha, M.W. Wlzinga, S.W. Tong, R. Zak, S. Jakovicic, and M. Rabinowitz. 1983. Cloned mRNA sequences for two types of embryonic myosin heavy chains from chick skeletal muscle. J. Biol. Chem. 258 51965205.

Kenny-Mobbs, T. and P. Thorogood. 1987. Autonomy of differentiation in avian brachial somites and the influence of adjacent tissues. Development 100: 449-462.

Kopan, R., J.S. Nye, and H. Weintraub. 1994. The intracellular domain of mouse Notch: A constitutively activated repressor of myogenesis directed at the basic helix-loop-helix region of MyoD. Development 120: 2385-2396.

Koseki, H., J. Wallin, J. Wilting, Y. Mizutani, A. Kispert, C. Ebensperger, B. Herrmann, B. Christ, and R. Balling. 1993. A role for Pax-1 as a mediator of notochordal signals during the dorsoventral specification of vertebrae. Development 119: 649-660.

Krauss, S., J.P. Concordet, and P.W. Ingham. 1993. A functionally conserved homolog of the Drosophila segment polarity gene hh is expressed in tissues with polarizing activity in zebrafish embryos. Cell 75: 1431-1444.

Ku, M. and D.A. Melton. 1993. Xwnt-11: A maternally expressed Xenopus Wnt gene. Development 119: 1161-1173.

Kuratani, S., J.F. Martin, S. Wawarsik, B. Lilly, G. Eichele, and E.N. Olson. 1994. The expression pattern of the chick homeobox gene gMHox suggests a role in patterning of the limbs and face and in compartmentalization of the somites. Dev. Biol. 161: 357-369.

Lash, I., S. Holtzer, and H. Holtzer. 1957. An experimental analysis of the development of the spinal column. VI. Aspects of cartilage induction. Exp. Cell Res. 13: 292-303.

Lee, J.J., S.C. Ekker, D.P. von Kessler, J.A. Porter, B.I. Sun, and P.A. Beachy. 1994. Autoproteolysis in hedgehog protein biogenesis. Science 266: 1528-1537.

Lin, A.Y., C.A. Dechesne, J. Eldridge, and B.M. Paterson. 1989. An avian muscle factor related to MyoDl activates musclespecific promoters in nonmuscle cells of different germ-layer origin and in BrdU-treated myoblasts. Genes \& Dev. 3: 986996.

Marti, E., D.A. Bumcrot, R. Takada, and A.P. McMahon. 1995. Requirement of $19 \mathrm{~K}$ form of Sonic hedgehog for induction of distinct ventral cell types in CNS explants. Nature 375: 322-325

Miller, A.D. and G.J. Rosman. 1989. Improved retroviral vectors for gene transfer and expression. BioTechniques 7: 980-990.

Münsterberg, A.E. and A.B. Lassar. 1995. Combinatorial signals 
from the neural tube, floor plate and notochord induce myogenic bHLH gene expression in the somite. Development 121: $651-660$.

Olson, E.N. and W.H. Klein. 1994. bHLH factors in muscle development: Dead lines and commitments, what to leave in and what to leave out. Genes \& Dev. 8: 1-8.

Ordahl, C.P. 1993. Myogenic lineages within the developing somite. In Molecular basis of morphogenesis (ed. M. Bernfield), pp. 165-176. Wiley-Liss, New York.

Ordahl, C.P. and N.L. Douarin. 1992. Two myogenic lineages within the developing somite. Development 114: 339-353.

Ott, M.O., E. Bober, G. Lyons, H. Arnold, and M. Buckingham. 1991. Early expression of the myogenic regulatory gene, myf5 , in precursor cells of skeletal muscle in the mouse embryo. Development 111: 1097-1107.

Parr, B.A., M.J. Shea, G. Vassileva, and A.P. McMahon. 1993. Mouse Wnt genes exhibit discrete domains of expression in the early embryonic CNS and limb buds. Development 119: $247-261$.

Placzek, M., T.M. Jessell, and J. Dodd. 1993. Induction of floor plate differentiation by contact-dependent, homeogenetic signals. Development 117: 205-218.

Placzek, M., M. Tessier-Lavigne, T. Yamada, T. Jessell, and J. Dodd. 1990. Mesodermal control of neural cell identity: Floor plate induction by the notochord. Science 250: 985988.

Pourquie, O., M. Coltey, M. Teillet, C. Ordahl, and N.M. LeFouarin. 1993. Control of dorsoventral patterning of somitic derivatives by notochord and floor plate. Proc. Natl. Acad. Sci. 90: 5242-5246.

Pownall, M.E. and C.P. Emerson Jr. 1992. Sequential activation of three myogenic regulatory genes during somite morphogenesis in quail embryos. Dev. Biol. 151: 67-79.

Riddle, R.D., R.L. Johnson, E. Laufer, and C. Tabin. 1993. Sonic hedgehog mediates the polarizing activity of the ZPA. Cell 75: 1401-1416.

Roelink, H., A. Augsburger, J. Heemskerk, V. Korzh, S. Norlin, A. Ruiz i Altaba, Y. Tanabe, M. Placzek, T. Edlund, T.M. Jessell, and J. Dodd. 1994. Floor plate and motor neuron induction by vhh-1, a vertebrate homolog of hedgehog expressed by the notochord. Cell 76: 761-775.

Roelink, H., J.A. Porter, C. Chiang, Y. Tanabe, D.T. Chang, P.A. Beachy, and T.M. Jessell. 1995. Floor plate and motor neuron induction by different concentrations of the amino-terminal cleavage product of sonic hedgehog autoproteolysis. Cell 81: 445-455.

Rong, P.M., M.A. Teillet, C. Ziller, and N.M.L. Douarin. 1992. The neural tube/floor plate/notochord complex is necessary for vertebral but not limb and body wall striated muscle differentiation. Development 115: 657-672.

Smith, W.C. and R.M. Harland. 1991. Injected Xwnt-8 RNA acts early in Xenopus embryos to promote formation of a vegetal dorsalizing center. Cell 67: 753-765.

Smith, J.L. and G.C. Schoenwolf. 1989. Notochordal induction of cell wedging in the chick neural plate and its role in neural tube formation. J. Exp. Zool. 250: 49-62.

Sokol, S., J.L. Christian, R.T. Moon, and D.A. Melton. 1991. Injected Wnt RNA induces a complete body axis in Xenopus embryos. Cell 67: 741-752.

Stern, H.M. and S.D. Hauschka. 1995. Neural tube and notochord promote in vitro myogenesis in single somite explants. Dev. Biol. 167: 87-103.

Stern, H.M., A.M.C. Brown, and S.D. Hauschka. 1995. Myogenesis in paraxial mesoderm: Preferential induction by dorsal neural tube and by cells expressing Wnt-l. Development 121: $3675-3686$.
Takada, S., K.L. Stark, M.J. Shea, G. Vassileva, J.A. McMahon, and A.P. McMahon. 1994. Wnt-3A regulates somite and tailbud formation in the mouse embryo. Genes \& Dev. 8: 174 189.

van Straaten, H.W.M., J.W.M. Hekking, E.L. Wiertz-Hoessels, F. Thors, and J. Drukker. 1988. Effect of the notochord on the differentiation of a floor plate area in the neural tube of the chick embryo. Anat. Embryol. 177: 317-324.

Vivarelli, E. and G. Cossu. 1986. Neural control of early myogenic differentiation in cultures of mouse somites. Dev. Biol. 117: 319-325.

Watterson, R., I. Fowler, and B.J. Fowler. 1954. The role of the neural tube and notochord in development of the axial skeleton of the chick. Am. J. Anat. 95: 337-400.

Weintraub, H. 1993. The MyoD family and myogenesis: Redundancy, networks, and thresholds. Cell 75: 1241-1244.

Wong, G.T., B.J. Gavin, and A.P. McMahon. 1994. Differential transformation of mammary epithelial cells by Wnt genes. Mol. Cell Biol. 14: 6278-6286.

Yamada, T., M. Placzek, H. Tanaka, J. Dodd, and T.M. Jessell. 1991. Control of cell pattern in the developing nervous system: Polarizing activity of the floor plate and notochord. Cell 64: 635-647.

Yamada, T., S.L. Pfaff, T. Edlund, and T.M. Jessell. 1993. Control of cell pattern in the neural tube: Motor neuron induction by diffusible factors from notochord and floor plate. Cell 73: 673-686. 


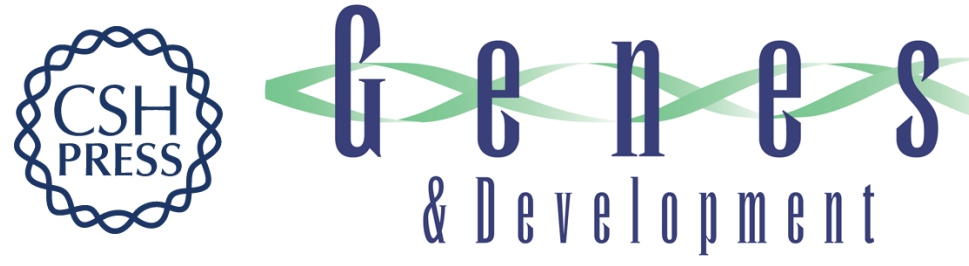

\section{Combinatorial signaling by Sonic hedgehog and Wnt family members induces myogenic bHLH gene expression in the somite.}

A E Münsterberg, J Kitajewski, D A Bumcrot, et al.

Genes Dev. 1995, 9:

Access the most recent version at doi:10.1101/gad.9.23.2911

References This article cites 67 articles, 28 of which can be accessed free at:

http://genesdev.cshlp.org/content/9/23/2911.full.html\#ref-list-1

License

Email Alerting

Service

Receive free email alerts when new articles cite this article - sign up in the box at the top right corner of the article or click here.

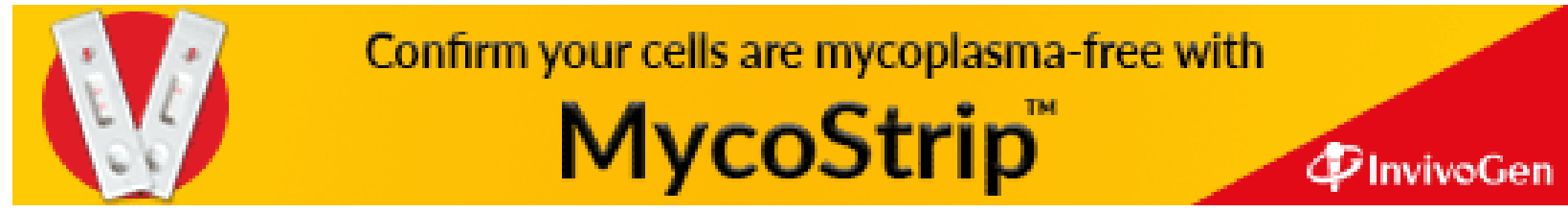

